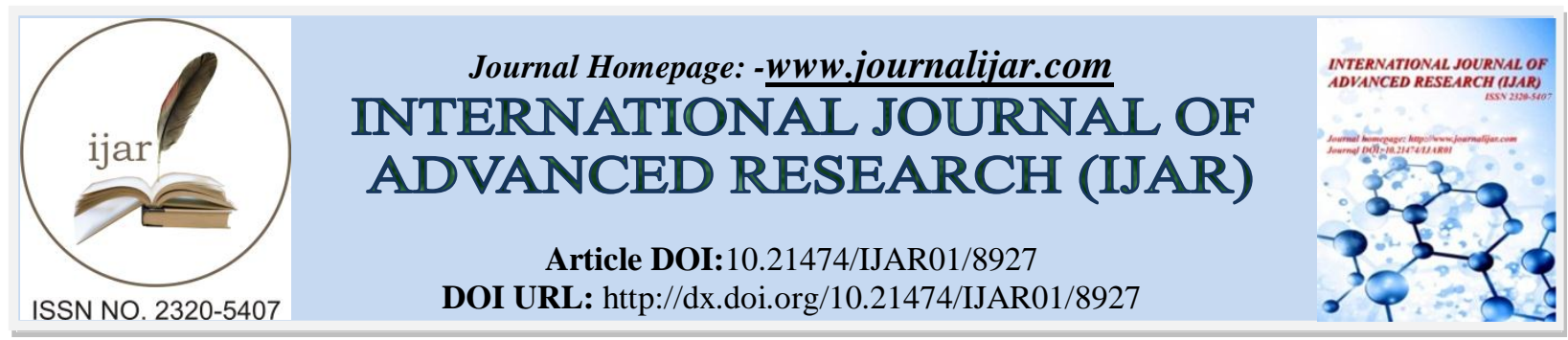

RESEARCH ARTICLE

\title{
BENEFITS AND CHALLENGES OF THE FREETOWN TEACHERS COLLEGE DISTANCE EDUCATION PROGRAMME FOR SERVING PRIMARY AND JUNIOR SECONDARY SCHOOL TEACHERS IN SIERRA LEONE.
}

\author{
Mohamed Shaw ${ }^{1}$ and Alpha Bassie Mansaray ${ }^{2}$. \\ 1. Freetown Teachers College, Kossoh Town-Hastings, Freetown. \\ 2. Njala University, Njala Campus.
}

\section{Manuscript Info}

\section{Manuscript History}

Received: 21 February 2019

Final Accepted: 23 March 2019

Published: April 2019

Key words:-

Benefits, Challenges, Distance

Education, Serving teachers

\begin{abstract}
The study investigated the benefits and challenges of the Freetown Teachers College Distance Education Programme for serving primary and junior secondary school teachers in Sierra Leone. The distance learners here are referred to as student-teachersor serving teachers. The distance education programme of Freetown Teachers College has been in operation for over a decade now. It has been receiving and continues to receive and turn out student-teachers in the Teachers Certificate and Higher Teachers Certificate primary and secondary programmes. This study ascertained the success story and challenges of the institution as a service provider of distance education among, which are cost effectiveness and inadequate equipment and facilities respectively.

The study targeted respondents from the existing nine campuses. Two hundred $(n=200)$ students-teachers, nine $(n=9)$ administrators and fifty $(n=50)$ tutors formed the sample which was drawn by simple random sampling taking cognizance of gender and programme of study. Data was collected using a well-structured questionnaire, interview and observation. Data generated from the above instruments were entered into IBM SPSS version 22 software and analyzed using descriptive statistical analysis, cross tabulation and correlation.

Participants responded to interviews and completed a questionnaire. Observation of respondents with the aid of an observation check list also formed part of the data collection drive.

Results from the study indicated some benefits in the distance education programme since its inception, but not without challenges. The benefits and challenges were highlighted, discussed, conclusions drawn and recommendations made. The findings and conclusions are relevant for other institutions in the drive to providing or already providing distance education programmes in Sierra Leone.
\end{abstract}

Copy Right, IJAR, 2019,. All rights reserved.

\section{Introduction:-}

The Distance Education Programme at the Freetown Teachers College was established in 2001/2002 with its Vision Statement as follows: Freetown Teachers College is to be a first class Teacher Training College of academic 
excellence and innovation and committed to producing qualified, dedicated and polyvalent teachers for active contribution to sustainable national development.

The Mission Statement of the institution states as follows: To create a conducive environment for the attainment of excellence in teaching, learning, research and management, placing premium on quality assurance in quality delivery, to train and produce qualified teachers for effective and efficient teaching and learning in Sierra Leone, to create an opportunity for all to access quality teacher education, skills competencies and functional knowledge and to empower youths and adults in the community and the nation at large to be self-reliant.

Tutors for the programme are recruited from graduate teachers from schools in the locations where the centres are established. The programme is funded by the Freetown Teachers College administration and development partners who provide grants to some of the student-teachers enrolled in the programme.It is supervised and monitored by the National Coordinator, Assistant Coordinators and Centre Supervisors.

The history of distance education; correspondence education, as it was earlier known, can be traced as far back as the 1800's during the agrarian era. It was delivered using the post where the teacher would send students learning materials and assignments by mail. Students would then complete the assignments and send them back. Teachers would send back their comments and critiques, along with a new assignment. In 1840 the, Englishman, Sir Isaac Pitman offered a class on shorthand taught entirely by mail [9.31]. Distance education was established out of a need for educational opportunities to reach a geographically dispersed population; the first distance learning was in the form of correspondence courses as mentioned earlier. Other more advanced forms did not emerge until the onset of the industrialization age in the 1920s. Developments in new technology from the late 1920s to 1970 saw distance learning opportunities grow through the use of radio and television. By 1970, the world had begun to focus on the power of the computer and distance learning entered the virtual age. [8]

Distance Education otherwise referred to as distance learning is a form of education which has been created with the aim of delivering education among those students who are not able to attend regular school due to various reasons. It can also be defined as an education system geared towards creating as well as offering access to learning in a situation where the source of education and learner are away from each other because of time and distance. In brief, it is an ideal way to offer education of equal quality to meet the educational requirement of a learner outside the classroom. This method of education is being adopted by a huge number of universities and institutes around the world. [19]

The Freetown Teachers College Distance Education Programme has nine centres nationwide, including, Freetown, Moyamba, Mile 91, Kambia, Pujehun, Matru Jong,,Kailahun and Kono (Koidu and Sewafe). Serving teachers are enrolled into the programme by applying and meeting the requirements for enrollment into the courses of their choice.. The programmes offered include; The Teachers Certificate (TC) and the Higher Teachers Certificate (HTC Primary and Secondary). Lectures are delivered through pre-prepared modules and periodic face-to-face sessions at the various centres.

Since its establishment, the distance education programme at Freetown Teachers College has attracted lots of serving teachers who have overwhelmingly accepted the programme and have enrolled for the Teachers Certificate and Higher Teachers Certificate (primary and secondary) programmes offered via distance education. Distance Education has been adopted by many institutions recently in Sierra Leone. There are about five higher educational institutions offering distance learning programmes in Sierra Leone. This shows the growth in distance education. Virtual schools are becoming important in many location.[6]. Against the background of this rapid growth, critics and admirers of the programme would be interested to know the delivery processes; benefits derived and the challenges faced by both the service providers and the beneficiaries.

The types of distance education can be determined by whether the tutor and learner are present at the same time irrespective of the distance, time and place. When teaching and learning takes place simultaneously, this situation is termed as synchronous situation, which means 'at the same time". Synchronous instruction requires the simultaneous participation of all students and instructors. On the other hand, asynchronous instruction is where students choose their own instructional time frame and interact with the learning materials and instructor according to their schedules". [8] The Freetown Teachers College Distance Education programme however is indicative of a blend of both situations, hence it is hybrid in context. Instructors and student-teachers meet during vacations for the 
traditional education system which gives room to student teachers to avail themselves of the face-to-face contacts with instructors.

This means the Freetown Teachers College distance learning programme is a blend of both synchronous and asynchronous instruction where there is a face to face meeting as well as through pre-prepared modules, telephones and internet chats.

Currently in Sierra Leone, thousands of students making up of primary and secondary school teachers have achieved certification through Distance Education programmes delivered either entirely online or through synchronous and asynchronous means or both, as in the case of Freetown Teachers College. Today's technology allows for many different methods of delivery, from online chat and advanced email services to video and conferencing media allowing real-time instruction[8].

The number and quality of student-teachers produced under any system of learning be it distance, or traditional face to face education, is determined by the training institution and the related human and material resources at its disposal to carry out the teaching and learning process. With quality, the dynamics of the student-learners constitute basic endowment like their calibre, motivation, mental preparedness, psychological soundness, and their financial strength, which are prerequisites to their success and the success of the institution. Programme outcomes and assessment for distance programmes, as for traditional programmes, must be a part of distance education programmes [12].

Considering the growth in human population in Sierra Leone and the quest for education, especially with the present pronouncement of the free basic and secondary education, there is bound to be a population explosion of pupils entering school. This explosion subsequently calls for the training of more teachers to cope with the pupil-teacher ratio. The number of teachers over the years has not marched the pupil population in schools and unqualified teachers have most often step in to fill this gap. This is simply because the number of teachers trained by teacher training institutions is less than required, which has led to the increased use of the untrained and unqualified teachers. In 2004 about 62,000 pupils took the National Primary School Examination ( NPSE) and 80\% entered the Junior Secondary School (JSS). In 2005 about 79,000 took the same NPSE carry over, 80\% again entered the JSS [21].

Many adults are unable or unwilling to attend traditional educational institutions and sit in the lecture rooms for many reasons including: having jobs, attending to family obligations and low income level. These and the dearth of accommodation and public transportation systems in the cities where they can accesses higher educational institutions have always been challenging. Against this background, student-learners who can't attend traditional classes because of these realities need alternatives. Hence the need for a well-organized distance education environment for them, with a well-designed instructional blueprint, state of the art technological equipment and adequate support and funding from administrators and government cannot be overemphasized.

Education is a process; considering the human dynamics involved and the socio-economic status of the country coupled with the high cost of technological gadgets and donor fatigue of development partners in education and above all the introduction of the free quality basic and secondary education by the government of Sierra Leone, it would seem a herculean task to carry on with a distance education programme. The significance of this study therefore cannot be overemphasized as it aims to highlight the benefits and challenges of the distance education programme at the Freetown Teachers College.

\section{Review of Literature}

The 2004 Education Act of Sierra Leone makes provision for the establishment of distance education programme as spelt out in Part 1, clause number 1, fourth interpretation, states that "distance education" means a method of delivering education to students with minimum direct contact with teachers.[27] It is apparent that the distance education programme is an offshoot of the non-formal education programme as stated in the Education Act of 2004.Part 11 clause number1, which states that, In order to make education accessible to every citizen, and to improve the literacy rate, the Minister shall establish an autonomous Council to be known as the Non-Formal Education Council to be responsible for developing and implementing programmes for adult and non-formal education in Sierra Leone. [27] 
Part 9, clause 3(g) of the same act states for the purpose of tertiary or higher educational institutions to contribute to the accelerated enhancement of literacy and the widening of educational opportunities in Sierra Leone [27].This is thus reflected in the vision and mission statements of Freetown Teachers College for establishing the Distance Education programme so as to widen the educational opportunity in Sierra Leone. In this regard education would reach the doorstep of all. Governments have adopted a variety of strategies for expanding the supply of teachers, raising their morale, supporting their work and improving their skills. One of these strategies involves using distance education.

From time immemorial, teacher-lecturing/ student-listening was the primary mode of traditional academic education. The delivery system for higher education has been a classroom setting with a professor giving a lecture and students listening and writing notes. Interaction between the professor and student has been viewed as an essential learning element within this arrangement, often referred to as the "sage on the stage." The organization, culture and practice of distance education has thus changed [9].

A study was done to provide an answer to the question of "quality" of Distance Education programmes: The study investigated thus: "Is there a difference in the quality of learning outcomes of Distance Education programmes compared to traditional face to face programmes?" A meta-analytical approach was adopted to synthesize various research studies in this field, and to examine differences between the two methods of delivery. Research conducted between 1952 and 1992, showed that Distance Education outcomes were not that different from those achieved in traditional classrooms. Phipps and Merisotisin, in their review of Distance Education programmes, reported:that the learning outcomes of students using technology at a distance are similar to the learning outcomes of students who participate in conventional classroom instruction. The attitudes and satisfaction of students using distance education also are characterized as generally positive [23]. Most of these studies conclude that, regardless of the technology used, distance education courses compare favourably with classroom-based instruction and enjoy high student satisfaction[23].

Results indicative of the research on the field of distance education as a matter of fact, show clearly that instruction delivered to distant learners is effective and that learning outcomes can be successfully attained when offered to students at a distance $[25,26]$. Hence the no significant difference phenomenon expressed.

In reviewing the significant theoretical developments and contributions to the study of distance education, Garrison noted that, it will be shown that the study of distance education in the $20^{\text {th }}$. Century was primarily focused on distance constraints and approaches that bridged geographical constraints by way of organizational strategies such as the mass production and delivery of learning packages. This has generally been identified as the industrial era of distance education. More recently, we shall see that the focus in the study of distance education has shifted to educational issues associated with the teaching-learning transaction, specifically, the concerns regarding real, sustained communication, as well as emerging communications technology to support sustained communication anytime, anywhere [11].

The technology required to participate in a distance learning class must be readily available and fully functional. Furthermore, students must have acquired certain level of competency with the technology including hardware, software and other related accessories in order to be successful in the course. Technology that is unavailable or unstable quickly becomes a barrier for distance learning students. Technology that is hard to learn or use is enormously frustrating either [18].

Technological improvements such as printing machines, postal services, telephone, radio, television, and more recently the Internet, have been a driving force yielding new delivery methods and platforms for distance education. These new learning methods used to deliver distance education (DE) are proliferating exponentially in various learning programmes, and leading some experts to predict that the "residential based model," in the form of students attending classes at prearranged times and locations, will disappear in the near future [7,22]. Although an expensive option today, video conferencing may create a virtual feeling that we are "back in the classroom." Some forms of DE has progressed in concept and practice from an "anywhere," to an "anytime," to an "any pace" delivery method. There are several factors that have made distance learning possible. One of these factors is the development in information technology [1].Information technology has provided the infrastructure that makes distance learning possible. Technologies such as; audio and video recording, telephone, video conferencing and computers have made it possible for information to be issued in one area and be received in another area. Though all these technologies are 
worth mentioning, they do not match the contribution made by the internet towards the development of distance technology [5]. The internet completely revolutionized the way people communicate making it possible for students and teachers to communicate in real time. The internet also made it possible for parties to communicate and get immediate feedback as well as increase the students' access to educational information.

Distance Education or long-distance learning is the education of students who may not always be physically present at a school. Traditionally, this usually involved correspondence courses wherein the students correspond with the school via post, Today it involves online education. Courses that are conducted (51\% or more) are either hybrid blended or $100 \%$ distance learning [30]

Distance education or distance learning is conventionally defined as "any educational or learning process or system in which the teacher and instructor are separated geographically or in time from his or her students; or in which students are separated from other students or educational resources. Contemporary distance learning is effected through the implementation of computer and electronics technology to connect teacher and student in either real or delayed time or on an as-needed basis. Content delivery may be achieved through a variety of technologies, including satellites, computers, cable television, interactive video, electronic transmissions via telephone lines, and others. Distance learning does not preclude traditional learning processes; frequently it is used in conjunction with in-person classroom or professional training procedures and practices it is also called distributed learning" [9]. Against this background, distance education programme has to be properly managed by administrators in order to realize its objectives. However, introduction of distance learning brought about several benefits to the society. One of the greatest benefits is that it increased the accessibility of people to higher education [20]. Prior to the development of distance learning, millions of students were forced to compete for few education opportunities that the prevailing physical education institution could support. This implies that millions of students were denied access to higher education. Introduction of distance learning provided a drastic boost to the capacity of education institution to offer higher education. More and more students were able to enroll into these institutions and get opportunity to build better lives. Distance learning also provides the benefit of lower cost [20].

Open Distance Education Learning (Odell) refers to "forms of education provision that use contemporary technologies to enable varied combinations of synchronous and asynchronous communication among learners and educators who are physically separated from one another for part or all of the educational experience" [3]. Odell expands the term "open and distance learning" or ODL to include use of e-learning or online learning methodologies to enable multiple forms of interaction and dialogue that can bridge the distance between teachers and learners [4, 11] and provide access to a vast array of interactive and multimedia learning resources that can be used to design learning environments for learners in diverse circumstances [2, 16]. Using online portals and virtual learning environments (VLEs) further enables distance education institutions to support both independent learning and collaborative learning through "increasingly complex pedagogical structures"[15].

In sub-Saharan Africa, political instability and economic depression have caused a decline in educational standards in some countries. As the population increased in these countries, a tremendous classroom shortage emerged, and both the number of qualified teachers and the availability of instructional materials became inadequate. Distance education is seen as having the potential to contribute to national reconstruction by providing economically feasible educational opportunities to many people. Collaboration with a variety of international distance education organizations has provided expertise and support for the practice of distance education. As a result, distance education at a basic level, as it is practiced in many regions of Africa, has expanded quite sharply. However, although growth in distance education in sub-Saharan African countries is evident, it does not yet have a wide impact. Lack of funding prevents distance education institutions from reaching many potential students [10, 28, 29]. The African Council for Distance Education (ACDE) is a continental educational organization comprising African universities and other higher education institutions, which are committed to expanding access to quality education and training through open and distance learning. It is registered under the laws of Kenya as an International NGO. As a unifying body of distance education providers and practitioners in Africa, the ACDE was formally launched in January 2004 at Egerton University, Kenya. In August 2005 the ACDE held its Inaugural Conference and General Assembly at the University of South Africa (UNISA) in Pretoria, during which it was resolved to establish a permanent ACDE Secretariat in Nairobi, Kenya. [16]

Distance education has been used most often to train primary-school teachers, but there is some experience of its use for secondary and tertiary teachers. Some courses have been aimed at the initial training of teachers who are entering 
the teaching force, some for initial training of those who have already worked as teachers for some years, while others are for the continuing education of those who are experienced and qualified but want to use distance education as a way of upgrading their qualifications and increasing their skills [12]

The Teacher Training Initiative for Sub-Saharan Africa (TTISSA) contributes to improve access, quality and equity of education through improving the quality and quantity of the teaching force in the region. The initiative supports the region's member states in addressing teacher-related challenges over a period of ten years (2006-2015). [17] In Sierra Leone the situation is partially arrested by the collaborative efforts of education partners'like United Nations Children Emergency Fund (UNICEF), Teacher Development Initiatives (TDI), PLAN Sierra Leone TDI plus Distance Education DE, Norwegian Refugee Council, Complementary Rapid Education for Primary schools (CREPS) among others to close the gaps. [21]

There had been increasing use of untrained and unqualified teachers in schools. The core problem is in the shortage of trained teachers in adequate quantity. Obviously the training institutions do not produce enough qualified teachers to satisfy the increasing rate of school enrolment. According to a survey, there had been a 400 percent increase in enrolment and overcrowding at primary school level: 367,000 in 1996, 1.000,000 in 2002, 1.200,000 in 2005 and $1.300,000$ in 2006 [21]. This number continues to rise with the recent introduction of the free basic and secondary education.

For example the production of primary school teachers in the teacher training institutions is smaller than the demand, about $100-1000$ graduate per year. Ultimately the number of teachers trained is less than the required, which has led to the increasing use of the untrained and unqualified teachers. Similarly in 2004 about 62,000 pupils took the National Primary School Examination (NPSE) and 80\% entered the JSS in 2005 about 79,000 took the same NPSE.A carryoverof $80 \%$ again entered the JSS. The implication here is that more teachers are needed to be trained. [21] The teacher ceiling makes provision for teachers going on study leave thereby increasing the need for more teachers. The two-school system has also increased the demand for teachers. It is estimated that about 28,000 teachers are needed and government has made provision for that number.

Distance learning traditionally has provided access to instructional programs for students who are separated by time and/or physical location from an instructor. Distance learning has been thought of as prepackaged text, audio, and/or video courses taken by an isolated learner with limited interaction with an instructor or other students. This perspective is changing. Today information technologies and the Internet can allow rich interactive distance learning experiences that may surpass the interactivity of a traditional classroom.

Distance learning also reduced the cost of education making it affordable to majority of the population. Years ago it was evident that college education was expensive and many people had to do without it simply because they could not afford [24]. However, introduction of distance learning reduced the cost of education in a number of ways. One of them is by reducing the cost incurred by the institution in providing education [20]. Onsite learning would mean that an institution must have physical facilities to accommodate the students learning.

Distance learning provides the flexibility that allow individual who would not have the opportunity to physically attend lesson to learn [13]. Today people who have busy careers and families to take care of are not locked out of learning because the distance learning program provides the flexibility that such people need. In modern days people can go to work during the day and learn in the evening at the comfort of their homes thanks to the technologies that enable distance learning. Professionals are also able to pursue their desired programs without having to interfere with the schedules of their careers. These technologies also favor people who would otherwise be disadvantaged by onsite learning such as the physically challenged.

\section{Methodology:-}

The study is a descriptive survey with a blend of quantitative and qualitative outlook. The researchers used questionnaires, interview to solicit response from respondents and personal observation. The study employs a mixed method approach to overcome some of the weaknesses that may characterize any one dominant model.

Primary and secondary data were collected. Textbooks, journals web sites and policy documents were accessed to collect secondary data while primary data was collected by the researchers with the use of instruments earlier mentioned together with observation. Participants in the research constituted the students-teachers, tutors/instructors 
and administrators. The sample was drawn by simple random sampling method with due diligence to age, gender and programme of study. The sample comprised of student-teachers $(n=200)$, Instructors/Lecturers $(n=50)$ and nine administrators $(\mathrm{n}=9)$.

Respondents were reached when the programme was in session and the researchers spent an academic year in their investigations with visits to the various centres and communicating with respondents online. Questionnaires were administered by hand and in some cases on line.

\section{Analysis and Discussion:-}

Table 1:-shows cross tabulation on quality, quantity and supply of instructional materials with available infrastructure for the programme.

\begin{tabular}{|l|l|l|l|l|l|l|}
\hline & & \multicolumn{3}{l|}{ Infrastructure for programme. } & \\
\hline & & & Inadequate & Average & Adequate & Total \\
\hline $\begin{array}{l}\text { Instructional } \\
\text { materials }\end{array}$ & Unsatisfactory & Count & 28 & 18 & 1 & 47 \\
\hline & & $\begin{array}{l}\% \text { instructional } \\
\text { materials }\end{array}$ & $59.6 \%$ & $38.3 \%$ & $2.1 \%$ & $100.0 \%$ \\
\hline & & $\%$ Infrastructure & $19.2 \%$ & $37.5 \%$ & $16.7 \%$ & $23.5 \%$ \\
\hline & & $\%$ of Total & $14.0 \%$ & $9.0 \%$ & $0.5 \%$ & $23.5 \%$ \\
\hline & Average & Count & 62 & 16 & 2 & 80 \\
\hline & & $\begin{array}{l}\text { instructional } \\
\text { materials }\end{array}$ & $77.5 \%$ & $20.0 \%$ & $2.5 \%$ & $100.0 \%$ \\
\hline & & $\%$ Infrastructure & $42.5 \%$ & $33.3 \%$ & $33.3 \%$ & $40.0 \%$ \\
\hline & & $\%$ of Total & $31.0 \%$ & $8.0 \%$ & $1.0 \%$ & $40.0 \%$ \\
\hline & Good & Count & 56 & 14 & 3 & 73 \\
\hline & & $\begin{array}{l}\% \text { instructional } \\
\text { materials }\end{array}$ & $76.7 \%$ & $19.2 \%$ & $4.1 \%$ & $100.0 \%$ \\
\hline & & $\%$ Infrastructure & $38.4 \%$ & $29.2 \%$ & $50.0 \%$ & $36.5 \%$ \\
\hline & & $\%$ of Total & $28.0 \%$ & $7.0 \%$ & $1.5 \%$ & $36.5 \%$ \\
\hline & & Count & 146 & 48 & 6 & 200 \\
\hline & & $\begin{array}{l}\% \text { instructional } \\
\text { Total }\end{array}$ & $73.0 \%$ & $24.0 \%$ & $3.0 \%$ & $100.0 \%$ \\
\hline & & $\%$ Infrastructure & $100.0 \%$ & $100.0 \%$ & $100.0 \%$ & $100.0 \%$ \\
\hline & & $\%$ of Total & $73.0 \%$ & $24.0 \%$ & $3.0 \%$ & $100.0 \%$ \\
\hline
\end{tabular}

Of the total respondents in the sample ( $\mathrm{n}=200), 47(23.5 \%)$ responded that the quality, quantity and supply of learning materials is unsatisfactory.80( $40 \%$ ) stated that quantity, quality and supply of learning materials were on the average, while $73(36.5 \%)$ stated that the quality, quantity and supply of their learning materials were good.

In the area of available infrastructure for the programme, 146(73.0\%) responded that infrastructure for the programme was inadequate. $48(24.8 \%)$ affirmed that infrastructure was on the average and $6(3.0 \%)$ respondents said infrastructure was adequate. 
Figure 1:-shows bar chart on the quality. Quantity and supply of learning materials

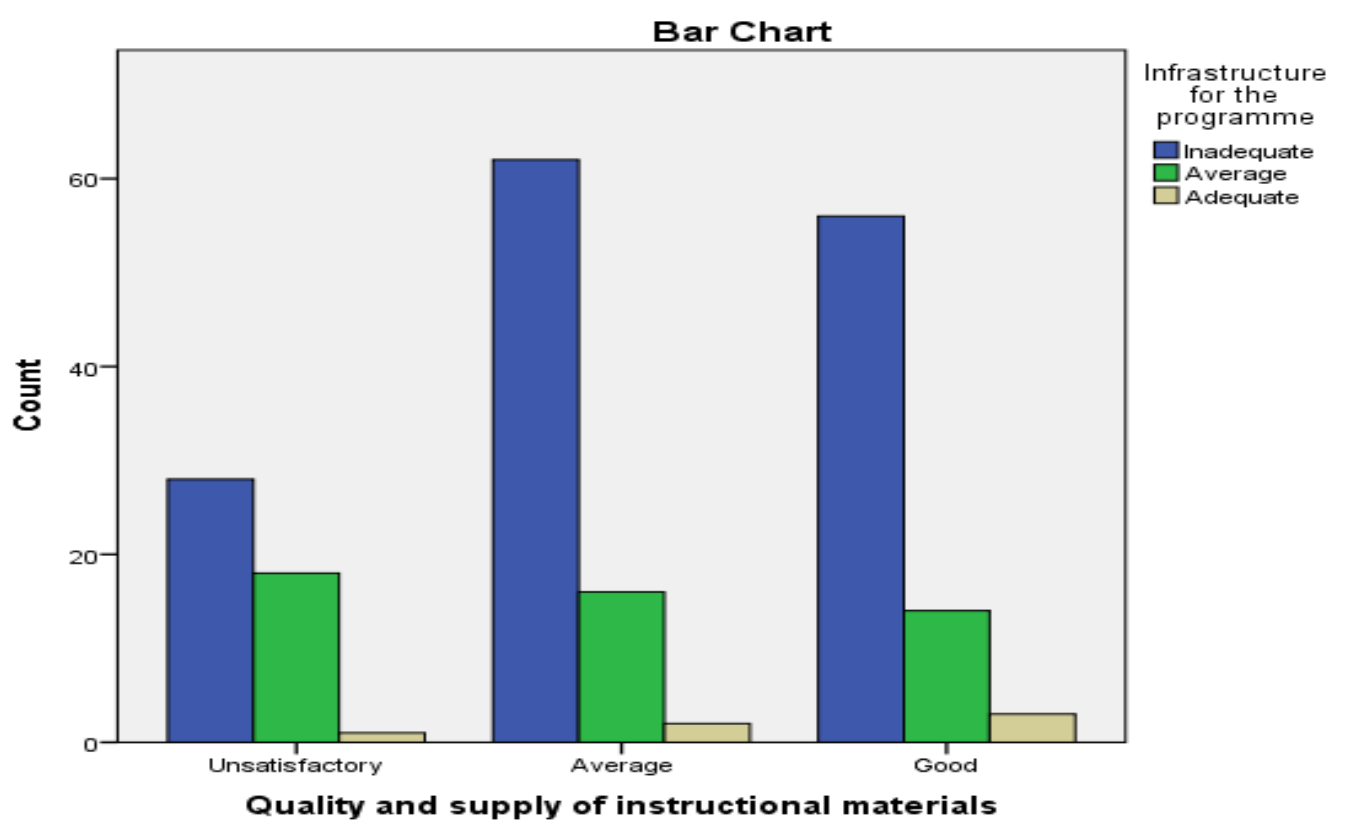

Table 2:-shows correlation analysis between assessment procedures and quality, quantity and supply of learning materials.

\begin{tabular}{|c|c|c|c|}
\hline & & $\begin{array}{l}\text { Assessment } \\
\text { procedures for } \\
\text { students }\end{array}$ & $\begin{array}{l}\text { Quality, quantity and supply } \\
\text { of instructional materials }\end{array}$ \\
\hline \multirow{3}{*}{$\begin{array}{l}\text { Assessment procedures for } \\
\text { students }\end{array}$} & Pearson Correlation & 1 & $.201^{* *}$ \\
\hline & Sig. (2-tailed) & & .004 \\
\hline & $\mathrm{N}$ & 200 & 200 \\
\hline \multirow{3}{*}{$\begin{array}{l}\text { Quality, quantity and supply of } \\
\text { instructional materials }\end{array}$} & Pearson Correlation & $.201^{* * *}$ & 1 \\
\hline & Sig. (2-tailed) & .004 & \\
\hline & $\mathrm{N}$ & 200 & 200 \\
\hline
\end{tabular}

Correlation analysis between assessment procedures for students and the quality, quantity and supply of instructional materials show a significant correlation at the 0.01 level ( 2 tailed)

Table 4:-shows cross tabulation on the benefits of the distance education programme to student-teachers.

\begin{tabular}{|c|c|c|c|c|c|c|c|}
\hline & \multicolumn{4}{|c|}{ What are the gains realized so far? } & \multirow[t]{2}{*}{ Total } \\
\hline & & & 1 and 2 & $1,2,3$ and 4 & $\begin{array}{l}1,2,4 \text { and } \\
5\end{array}$ & $\begin{array}{l}1,2,3,4 \\
\text { and } 5\end{array}$ & \\
\hline \multirow{4}{*}{$\begin{array}{l}\text { Is the DE programme } \\
\text { gainful? }\end{array}$} & \multirow[t]{4}{*}{ yes } & Count & 26 & 93 & 62 & 19 & 200 \\
\hline & & $\begin{array}{l}\% \text { within Is the } \\
\text { DE programme } \\
\text { gainful? }\end{array}$ & $13.0 \%$ & $46.5 \%$ & $31.0 \%$ & $9.5 \%$ & $100.0 \%$ \\
\hline & & $\begin{array}{l}\% \text { within What } \\
\text { are the gains } \\
\text { realized so far? }\end{array}$ & $100.0 \%$ & $100.0 \%$ & $100.0 \%$ & $100.0 \%$ & $100.0 \%$ \\
\hline & & $\%$ of Total & $13.0 \%$ & $46.5 \%$ & $31.0 \%$ & $9.5 \%$ & $100.0 \%$ \\
\hline \multirow{3}{*}{\multicolumn{2}{|c|}{ Total }} & Count & 26 & 93 & 62 & 19 & 200 \\
\hline & & $\begin{array}{l}\% \text { within Is the } \\
\text { DE programme } \\
\text { gainful? }\end{array}$ & $13.0 \%$ & $46.5 \%$ & $31.0 \%$ & $9.5 \%$ & $100.0 \%$ \\
\hline & & $\%$ within What & $100.0 \%$ & $100.0 \%$ & $100.0 \%$ & $100.0 \%$ & $100.0 \%$ \\
\hline
\end{tabular}




\begin{tabular}{|l|l|l|l|l|l|l|}
\hline & $\begin{array}{l}\text { are the gains } \\
\text { realized so far? }\end{array}$ & & & & \\
\cline { 2 - 7 } & \% of Total & $13.0 \%$ & $46.5 \%$ & $31.0 \%$ & $9.5 \%$ & $100.0 \%$ \\
\hline
\end{tabular}

1=Certificate $2=$ Knowledge of IT $3=$ Accessibility to education $4=$ social networking $5=$ cost effective

In response to the gains of the distance education programme, all respondents stated that the programme was indeed beneficial.As to how it was beneficial to them,26(13\%) respondents that it has earned them certificates which have enhanced their capacity as teachers and also has enhanced their knowledge in Information Technology (IT) and the use of IT accessories.

Ninty-three $(46.5 \%)$ responded that it was gainful due to the acquisition of certificates,IT knowledge,accessibility to education social networking with colleges and learning at reasonable cost. Of the 200 respondents,62(31.1\%) responded benefiting by gaining a certificate, enhancement of their IT knowledge, social networking and learning at a relatively low cost.

$19(9.5 \%)$ respondents affirmed that they view distance learning as beneficial in that it has capacitated them in their job with the acquisition of certificate and the broadening of their horizon on IT and its use as well as empowered to take part in social networking over the internet and above all learning at a much reduced cost.

On the challenges faced by the studens, were inadequate facilities in their centres, unsatisfactory quality of modules as some contained series of typographical errors and illegible graphics. The modules are in short supply and are not supplied on time. Progress reports are not regularly done and sometimes published very late. Connectivity on line is another big challenge. Face-to-face contact periods are sometimes reduced. There were acute shortages of sitting accommodation for students at their centres as student-teachers were most time seen scrambling for seats.

Interview with instructors revealed that they work within limited means of teaching and learning materials which if not adequately addressed would impede service delivery. The instructors also raised concerns on the renumeration paid them which they described as meagre and most often not paid on time coupled with the inadequate staff training and development programmes.Those instructors who have however benefited from few IT training programmes said it was a unique opportunity as their level of IT has leveraged their capacity and that their recruitment into the distance education programme has complimented their earnings from their full-time places of work.

Smooth running of a distance education programme requires adequate financial support.The Freetown Teachers College distance education programme is peresonally funded by the college administration and with help from development partners or Non-governmental Organizations (NGO's). Inadequate support and funding posed a serious challenge for the administrators hence a reverberating effect on the delivery process.Notwithstanding the constrains faced by the administrators, the institution has scored successess in its distance education programme among which are: reduction of the huge number of untrained and unqualified teachers in the country, created access for many teachers to upgrade themselves, provided opportunities for teachers to learn and earn, and has enhanced effective and efficient teaching and learning in Sierra Leone. The Distance education programme has been also beneficial on the part of the institution as it has been cost effective operating in centers around the country rather than erecting lofty buildings for the purpose.

The benefit of the Freetown Teachers College Distance Education programme is that it has created an opportunity for teachers of basic and secondary education to access quality teacher education, skills, competencies and functional knowledge to promote education in Sierra Leone.

\section{Conclusion:-}

In conclusion, the Distance Education programme has been beneficial to student-teachers and the Sierra Leone community. With seventeen years in operation thousands of teachers have been empowered and are now professionally serving the teaching service with pride and confidence.

There are two sides to every coin. This is to say that the gains made by the institution over the years are not without challenges. The institution has sailed through turbulent waves to score some gains but the wherewithal is inadequate and has to be adequately addressed. 
The programme has provided access and enhances learning opportunities for those not being served in traditional programmes. It has provided access to persons not otherwise served in the traditional setting.

The high cost of education that affects students in traditional higher education, is much reasonable in the DE programme and has brought relief to students due to its cost effectiveness.

Working within limited resources however has not adversely affected student performance as distance learners were reportedly doing relatively better than the regular students.

Considering the benefits derived from the distance education programme and especially with the flagship project of the new direction government more pupils would be seen to be enrolled in schools hence subsequent provision has to be made for sustainable development of the programme so that it matches up by providing the much needed service with due diligence to quality and adequate infrastructure.

\section{Recommendations}

The Institution should try to transcend from more of print-based (modules) to online delivery using virtual learning environments (VLEs) and various Web technologies; and to make such technologies readily available to studentteachers for use.

Distance Learning materials should be appropriate and considered worthwhile. They should match up with studentteachers' goals. Efforts should be made to make sure that modules are regularly reviewed and such reviewed modules are pilot tested for typographical, graphics and other errors; there after modified as required.

Programme monitors and centre supervisors should identify the instruction strategies and materials and ensure that they fit the course curriculum.

The college Administration should outline procedures to regularly monitor and evaluate the programme, instructors, and student-teachers on formative and summative basis to ascertain the degree to which the distance education programme's objectives are met.

With growing cutting edge technology, Distance learning can be most effective and efficient when instructors, learners and administrators, acquire new knowledge and skills. Therefore regular staff training and development must be an integral part of the distance education programme.

Applicants for distance education programmes should continually be screened to ensure they meet admission requirements for the course programmes applied for in order to sustain the quality record of the institution over the years. Administrators should be strict on enrollment procedures and ensure that orientation for freshmen and women is conducted and similarly clearly define instructor/lecturer recruitment procedure, orientation, training, and development programmes.

Administrators should ensure that trained and qualified experts in the respective subject disciplines are contracted to regularly review and update the pre-prepared modules.

Most distance learning programmes use learning management systems (LMS) or course management systems (CMS) that incorporate course management, content, hyperlinks, email and chat communications, and grading systems. It is recommended that the Freetown Teachers College administration considers using this technology as it would help administrators plan, implement and assess the teaching and learning process with ease.

\section{References:-}

1. Adrianus C \& Herero A. (2010). Challenges for Open and Distance Learning in the Post-2010. August 12, 2011. www.elearningeuropa.info/en/download/file/fid/19494.

2. Alan Tait. "Reflections on Student Support in Open and Distance Learning". The International Review of Research in Open and Distance Learning.

3. Alfonso, G. J. (2012, August). UP Open University: Thoughts about openness in a digitized world [Power Point slides]. Presentation at the UPOU Roundtable Discussion, UPOU Oblation Hall, Los Banos, Laguna.

4. Anderson, T. (2008c). Teaching in an online learning context. In Anderson, T. (Ed.), The theory and practice of online learning (2nd ed; pp. 343-365). Alberta, Canada: Athabasca University Press. 
5. Armstrong L (2000). Distance Learning: Challenges and Questions. August 12, 2011. Retrieved from http://www.usc.edu/dept/chepa/pdf/distance_education.pdf.

6. Berge, Z., \& Clark, T. (2005). Virtual schools: Planning for success. New York: Teachers College Press.

7. Blustain, H., Goldstein, P., and Lozier, G. (1999). Assessing the New Competitive Landscape.In Richard N. Katz and Associates (Eds.) Dancing with the Devil. San Francisco: Jossey-Bass.

8. California adult basic education distance learning experience since 1995.:History of Distance Learning).

9. Cleveland-Innes, M. F. (2010). Teaching and learning in distance education: Enter a new era. In M. F. Cleveland-Innes \& D. R.Garrison (Eds.), An introduction to distance education: Understanding teaching and learning in a new era (pp.1-10). New York: Routledge

10. Day, B. (2005). Open and distance learning enhanced through ICTs: A toy for Africa's elite or an essential tool for sustainable development. In Visser Y., Visser L., Simonson M., \&Amirault R. (Eds.), Trends and issues in distance education: International perspectives (pp. 171-182). Charlotte, NC: Information Age Publishing.

11. Garrison, R. (2000). Theoretical challenges for distance education in the 21st century: A shift from structural to transactional issues. International Review of Research in Open and Distributed Learning, 1(1).Retrievedfrom http://www.irrodl.org/index.php/irrodl/article/view/2/22. Accessed September, 2018.

12. Gibson, T.H. (2006b). Appendix III\&IV - Evidence of Quality in Distance Education Programs. Retrieved March 14, 2008, from Montana Board of Regents Web site:http://mus.edu/board/meetings/2006/06-May/06May.asp/0506AgendaFullBOR.pdf, p 356-371.

13. Goodwin C. Graham M. \& Scarborough H. (2001). Developing an Asynchronous Learning Network. Educational Technology \& Society. 4 (4)

14. Haughey, M. (2010). Teaching and learning in distance education before the digital age. In Cleveland-Innes, MF \& Garrison, DR (Eds.). An Introduction to Distance Education. Understanding Teaching and Learning in a New Era. New York: Routledge.

15. Haughey, M., Evans, T., \& Murphy, D. (2008). Introduction: From correspondence to virtual learning environments. In T. Evans, M. Haughey, \& D. Murphy (Eds.), International handbook of distance education (pp. 1-24). Bingley, UK: Emerald Group Publishing Ltd.

16. Hawkridge, D., Kinyanjui, P., Nkinyangi, J. and Oriel, F. (1982): 'In-service teacher education in Kenya', in H.Perraton (Ed.): Alternative routes to formal education: distance teaching for school equivalency, Baltimore: Johns Hopkins University Press.

17. http://www.unesco.org/new/en/education/themes/education-building-blocks/teacher-education/ttissa/

18. https://classroom.synonym.com/problems-faced-students-distance-learning1303.html.Accessed September 2018.

19. https://www.ukessays.com/essays/education/an-introduction-to-distance-learning-education-essay.php?vref=1)

20. Ivankova N.(2007).Distributed Doctoral Program in Education Administration. August 12, 2011.Retrievedfrom http://www.sagepub.com/creswellstudy/Sample\%20Student\%20Proposals/Proposal-MM-Ivankova.pdf.

21. Joof A. E. (2006).The UNESCO teacher training initiative for sub-Saharan Africa (TTISSA)Teacher training initiative: the Sierra Leone perspective

22. O'Malley, J., and McCraw, H. (1999). Students Perceptions of Distance Education, Online Learning, and the Traditional Classroom. Online Journal of Distance education Administration, 2(4). Retrieved September 19, 2003 from: http://www.westga.edu/ distance/omalley24.html.

23. Phipps, R., \&Merisotis,J.(1999).What's the Difference-A review of contemporary Research on the Effectiveness of Distance learning in Higher Education. The Institute for Higher Education Policy.

24. Pityana B.(2009). Open Distance Learning in the Developing World. August 12, 2011. Retrieved from http://www.unisa.ac.za/contents/about/principle/docs/ICDEMaastricht250609.pdf

25. Russell, T. (1999). No significant difference phenomenon. Raleigh: North Carolina State University.

26. Russell.(2002). "The No Significant Difference Phenomenon" as reported in 355 research reports, summaries and papers - a comprehensive research bibliography on technology for distance education, retrieved 2003 from: http://teleeducation.nb.ca/nosignificantdifference/.

27. The education act, 2004 Sierra Leone Education Act-2004. Supplement to the Sierra Leone Gazette Vol. CXXXV, No. 19

28. Visser, L., \& West, P. (2005). The promise of M-learning for distance education in South Africa and other developing nations. In Y.Visser, L.Visser, M. Simonson, \& R. Amirault (Eds.), Trends and issues in distance education: International perspectives (pp. 131-136). Charlotte, NC: Information Age Publishing.

29. Visser, M., Visser, J., \&Buendia, M. (2005). Thank you for (not) forgetting us: A reflection on the trials, tribulations, and take-off of distance education in Mozambique. In Y.Visser, L.Visser, M. Simonson, \& R. 
Amirault (Eds.), Trends and issues in distance education: International perspectives (pp. 217-244). Charlotte, NC: Information Age Publishing.

30. Wikipedia: https//:en.m.wikipedia.org $>$ wiki<distance education

31. Williamson, J. (2009) .The History of Distance Education.http://distance-education.org/articles/the-history-ofdistance-education-113.html.Retrieved September, 2018. 